\title{
CORRELATION BETWEEN MACULAR CHANGES IN EXFOLIATION SYNDROME AND EXFOLIATIVE GLAUCOMA
}

\author{
Marija Šimić Prskalo ${ }^{1}$ Željka Tomić ${ }^{1}$, Katia Novak-Lauš ${ }^{2}$ and Zrinko Prskalo ${ }^{3}$ \\ ${ }^{1}$ Clinical Department of Ophthalmology, Mostar Univerity Hospital, Mostar, Bosnia and Herzegovina; ${ }^{2} \mathrm{Clinical}$ \\ Department of Ophthalmology, Sestre milosrdnice University Hospital Center, Zagreb, Croatia; ${ }^{3} \mathrm{Clinical}$ \\ Department of Internal Medicine, Mostar University Hospital, Mostar, Bosnia and Herzegovina
}

\begin{abstract}
SUMMARY - The aim of the study was to evaluate macular thickness and macular volume in unilateral and bilateral exfoliation syndrome and to compare them with exfoliative glaucoma and control eyes using optical coherence tomography. This prospective study included 114 subjects $(228$ eyes) divided into 4 groups according to the presence of exfoliation: 30 patients with unilateral syndrome, 24 patients with bilateral syndrome, 28 patients with bilateral glaucoma and control group without glaucoma or exfoliation syndrome (32 subjects). All subjects were older than 50 years. Patients with visual acuity under 0.6 according to Snellen were excluded, as well as those with refraction errors, i.e. hypermetropia over +3 spherical diopters, myopia over -5 spherical diopters, astigmatism over 2 cylindrical diopters, patients with affections that might affect the macula or the optic nerve, such as diabetic retinopathy, macular degeneration, macular edema, epiretinal membrane, vascular occlusions, neuropathies, and patients having undergone eye surgery except for pseudophakic patients with visual acuity within the set limits. Study results confirmed the hypothesis on the existence of structural changes of macular parameters before the functional ones, thus representing an early sign of glaucomatous damage in risk groups such as unilateral and bilateral exfoliation syndrome. If the glaucoma had already manifested (exfoliative glaucoma in this study) with changes in optic disc and visual field, structural changes confirmed the clinical findings and warned of the disease severity.
\end{abstract}

Key words: Macula; Glaucoma; Exfoliation syndrome

\section{Introduction}

Exfoliation syndrome (XFS) is an age-related disease characterized by the production and progressive accumulation of a fibrillar extracellular material in virtually all of the tissues of the anterior segment of the eye. It is not just a disease of the eye, but in addition deposits of exfoliation material can be found in blood vessels, extraocular tissues, and in diverse organs throughout the body.

Correspondence to: Katia Novak-Lauš, $M D, P h D$, Clinical Department of Ophthalmology, Sestre milosrdnice University Hospital Center, Vinogradska c. 29, HR-10000 Zagreb, Croatia

E-mail: katia@midij-com.hr

Received December 16, 2015, accepted December 30, 2015
Exfoliation syndrome is the most common identifiable cause of glaucoma worldwide, accounting for the majority of cases in some countries and causing both open-angle and angle-closure glaucoma ${ }^{1}$. In addition, involvement of the iris, lens and blood vessels leads to anterior segment hypoxia, chronic blood aqueous barrier breakdown, cataract and abnormalities of ocular blood flow. It has been estimated that approximately 60 to 70 million people in the world have XFS and 5-6 million people have glaucoma. The potential mechanisms of glaucoma in XFS include blockage of the meshwork by liberated iris pigment and exfoliation material, trabecular cell dysfunction and degenerative changes of Schlemm's canal. The prognosis of exfolia- 
tive glaucoma (XFG) is worse than that of primary open-angle glaucoma. There is a higher frequency and severity of optic nerve damage at the time of diagnosis, worse visual field damage, poorer response to medications, more severe clinical course and more frequent necessity for surgical intervention.

In addition to regular diagnostic procedures (Goldmann applanation tonometry, slit lamp examination, gonioscopy, perimetry and ophthalmoscopy), optical coherence tomography (OCT) has been shown to be a useful tool for diagnosing and evaluating glaucoma, based on the measurement of optic disc and peripapillary retina, as well as macular thickness parameters ${ }^{2,3}$.

In the macula, there are up to 10 rows of ganglion cells, with the largest concentration in the parafoveal region ${ }^{4}$. The ganglion cell layer together with the nerve fiber layer make approximately $30 \%-45 \%$ of macular thickness ${ }^{5}$. The ganglion cell loss in glaucoma leads to the reduction of the thickness and, implicitly, of the macular volume, as demonstrated by numerous studies.

The aim of the study was to evaluate macular thickness and macular volume in unilateral and bilateral XFS and to compare them to XFG and healthy subjects using OCT.

\section{Subjects and Methods}

The study included 114 subjects (228 eyes) divided into 4 groups according to the presence of exfoliation: 30 patients with unilateral XFS, 24 patients with bilateral XFS, 28 patients with bilateral XFG and control group without XFG or XFS (32 subjects). All subjects were older than 50 years. This prospective study was performed between January 2012 and October 2013 at the Clinical Department of Ophthalmology, Sestre milosrdnice University Hospital Center, Zagreb, Croatia. All subjects gave their informed consent for participation in the study. The Ethics Committee of the Sestre milosrdnice University Hospital Center approved the study. Ethical guidelines of the Declaration of Helsinki were followed during the study. All subjects underwent complete ophthalmologic examination including the following: medical history (including ocular and family histories), best corrected visual acuity, slit lamp examination, intraocular pressure measurement using Goldmann applanation tonometry, gonioscopy, dilated fundus examination using 78-diopter lens and Octopus $\mathrm{dG} 2$ visual field testing.

The main inclusion criteria were the presence of unilateral or bilateral XFS and/or bilateral XFG.

Patients with visual acuity under 0.6 according to Snellen were excluded, as well as those with refraction errors, i.e. hypermetropia with over +3 spherical diopters, myopia of over -5 spherical diopters, astigmatism of over 2 cylindrical diopters, patients with affections that might affect the macula or the optic nerve, such as diabetic retinopathy, macular degeneration, macular edema, epiretinal membrane, vascular occlusions, neuropathies, and patients having undergone eye surgery except for pseudophakic patients with visual acuity within the set limits.

Measurements of macular volume and macular thickness were done with the Cirrus spectral-domain high definition OCT (Carl Zeiss Meditec Inc., Dublin, CA, USA). By protocol analysis, macular thickness is measured in microns and macular volume in $\mathrm{mm}^{3}$.

\section{Statistical methods}

Results were expressed as descriptive statistics parameters, as follows: qualitative variables (i.e. those that are shown in comparison to reference values) were expressed as absolute and relative frequencies, whereas quantitative variables such as macular volume and mean macular thickness were expressed as arithmetic mean with correspondent standard deviation (SD) and as minimal and maximal measured values.

Differences in gender distribution and between the groups were tested with $\chi^{2}$-test. This test was used to test distribution of subjects in the groups within or beyond reference values in comparison to study groups.

Analysis of variance (ANOVA) was used to determine whether macular thickness and volume differed among the groups of subjects. When ANOVA yielded a statistically significant difference in measured values between study groups, Tukey HSD procedure was used to establish differences in variables for each study group.

\section{Results}

There were no differences in gender distribution among the groups $(\mathrm{p}=0.561)$ (Table 1$)$, but the groups differed statistically significantly according 
to age $(\mathrm{p}<0.001)$. The oldest was the bilateral XFG group, followed by the unilateral XFS group and control group. The youngest was the bilateral XFS group (Table 2).

Statistically significant between-group differences were found in the measured values of macular volume $(\mathrm{p}<0.001)$. Tukey HSD procedure revealed differences

Table 1. Gender distribution of study subjects

\begin{tabular}{|l|c|c|}
\hline \multirow{2}{*}{ Group } & \multicolumn{2}{|c|}{ Gender } \\
\cline { 2 - 3 } & Male & Female \\
\hline Unilateral XFS & $\mathrm{n}(\%)$ & $\mathrm{n}(\%)$ \\
\hline Bilatreal XFS & $14(40.00)$ & $18(60.00)$ \\
\hline Bilateral XFG & $14(50.00)$ & $10(41.67)$ \\
\hline Control & $14(43.75)$ & $18(50.00)$ \\
\hline Total & $54(47.37)$ & $60(52.63)$ \\
\hline
\end{tabular}

$\chi^{2}=2.06 ; \mathrm{p}=0.561 ; \mathrm{XFS}=$ exfoliation syndrome; $\mathrm{XFG}=$ exfoliative glaucoma

shown in Table 3. Macular volume was statistically significantly higher in the groups with unilateral XFS (fellow eyes), unilateral XFS, bilateral XFS and control group as compared with the bilateral XFG group $(\mathrm{p}<0.001)$. Statistically significant between-group differences were also recorded in the mean macular thickness $(p<0.001)$. Tukey HSD procedure revealed differences shown in Table 4 . The mean macular thickness in the group with unilateral XFS (i.e. XFS clinically manifested on one eye but clinically undetectable and only demonstrated by electron microscopy on the fellow eye) was statistically significantly different on
Table 2. Age distribution of study subjects

\begin{tabular}{|l|c|c|c|c|c|}
\hline Group & $\mathrm{n}$ & Min & Max & $\overline{\mathrm{x}}$ & SD \\
\hline Unilateral XFS & 30 & 66 & 86 & 77.67 & 5.79 \\
\hline Bilateral XFS & 24 & 63 & 86 & 71.25 & 5.96 \\
\hline Bilateral XFG & 28 & 73 & 89 & 80.39 & 4.04 \\
\hline Control & 32 & 66 & 86 & 75.69 & 5.68 \\
\hline
\end{tabular}

$\mathrm{F}=13.02(110 ; 3) ; \mathrm{p}<0.001 ; \mathrm{XFS}=$ exfoliation syndrome; $\mathrm{XFG}=$ exfoliative glaucoma

both eyes from the respective value measured in the group with bilateral XFG and control group ( $<<0.001)$. In the group with unilateral XFS, the mean macular thickness was higher as compared with the bilateral XFG group, but lower than the mean macular thickness in control group. In the bilateral XFS group, the mean macular thickness was statistically significantly higher than the respective value recorded in the bilateral XFG group $(p=0.007)$, but lower than the value in control group $(\mathrm{p}<0.001)$ (Figs. 1 and 2$)$.

\section{Discussion}

Optical coherence tomography allows measurement of macular thickness and macular volume in normal and glaucomatous eyes. Measurement of the ganglion cell layer is a more recent parameter used in glaucoma assessment. Approximately $54 \%$ of the ganglion cell bodies reside in the macula, so measuring this layer perhaps does not provide as much information as retinal nerve fiber layer (RNFL) or optic nerve head measurements since the latter measure $100 \%$ of their structures.

Table 3. Differences of macular volume among study groups

\begin{tabular}{|l|c|c|c|c|c|}
\hline & F & \multicolumn{2}{l|}{} \\
\cline { 1 - 3 } Macular volume & $24.3_{(223 ; 4)}$ & $<0.001$ & \multicolumn{2}{|l|}{} \\
\hline Macular volume & $\begin{array}{c}\text { Unilateral XFS } \\
\text { (fellow) }\end{array}$ & $\begin{array}{c}\text { Unilateral } \\
\text { XFS }\end{array}$ & $\begin{array}{c}\text { Bilateral } \\
\text { XFS }\end{array}$ & $\begin{array}{c}\text { Bilateral } \\
\text { XFG }\end{array}$ & Control \\
\hline Unilateral XFS (fellow eye) & & & & $<0.001$ & \\
\hline Unilateral XFS & & & & $<0.001$ & \\
\hline Bilateral XFS & & & & $<0.001$ & \\
\hline Bilateral XFG & $<0.001$ & $<0.001$ & $<0.001$ & & $<0.001$ \\
\hline Control & & & & $<0.001$ & \\
\hline
\end{tabular}

XFS = exfoliation syndrome; XFG = exfoliative glaucoma 
Table 4. Differences in the mean macular thickness among study groups

\begin{tabular}{|l|c|c|c|c|c|}
\hline & F & p & \multicolumn{2}{l}{} \\
\cline { 1 - 3 } Macular volume & $37.2_{(223 ; 4)}$ & $<0.001$ & \multicolumn{2}{l|}{} \\
\hline Mean macular thickness & $\begin{array}{c}\text { Unilateral } \\
\text { XFS }\end{array}$ & $\begin{array}{c}\text { Unilateral } \\
\text { XFS }\end{array}$ & $\begin{array}{c}\text { Bilateral } \\
\text { XFS }\end{array}$ & Bilateral XFG & Control \\
\hline Unilateral XFS (fellow eye) & & & & $<0.001$ & $<0.001$ \\
\hline Unilateral XFS & & & & $<0.001$ & $<0.001$ \\
\hline Bilateral XFS & & & & 0.007 & $<0.001$ \\
\hline Bilateral XFG & $<0.001$ & $<0.001$ & 0.007 & & $<0.001$ \\
\hline Control & $<0.001$ & $<0.001$ & $<0.001$ & $<0.001$ & \\
\cline { 1 - 3 }
\end{tabular}

$\mathrm{XFS}=$ exfoliation syndrome; $\mathrm{XFG}=$ exfoliative glaucoma

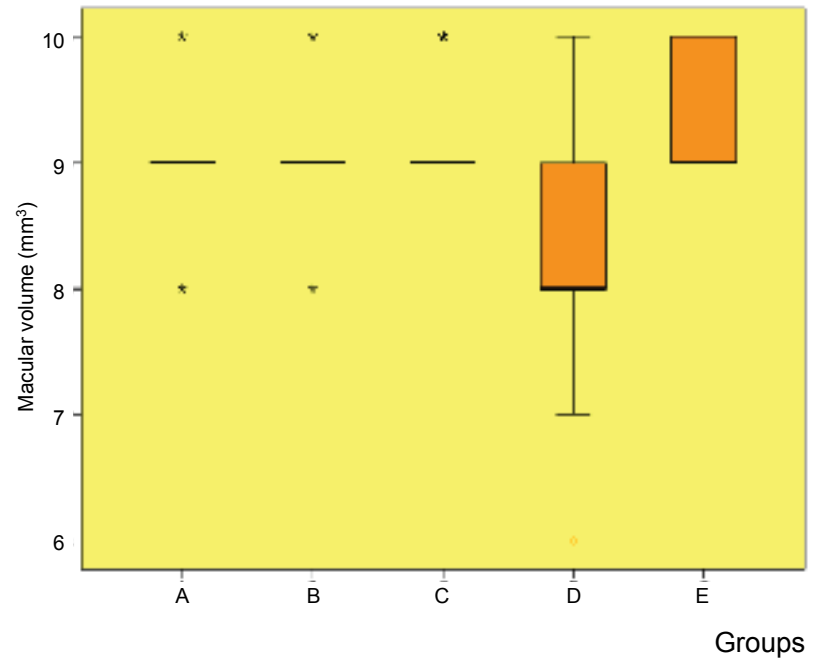

$\mathrm{A}=$ unilateral exfoliation syndrome (XFS) (fellow eye); $\mathrm{B}=$ unilateral XFS; C = bilateral XFS; D = bilateral exfoliative glaucoma; $\mathrm{E}=$ control; * reference values: 257.1-295 $\mu \mathrm{m}$

Fig. 1. Macular volume according to study groups.

From the data obtained in this study we conclude that in glaucomatous eyes the mean macular thickness and volume decrease significantly compared to normal eyes, and this has also been proven in similar studies $^{2,6-9}$. Macular thickness and volume are significantly lower in glaucoma. Decrease in macular volume is correlated with the decrease in macular thickness. The decrease is more significant in the eyes with more advanced glaucoma compared to suspect glaucoma and preperimetric glaucoma ${ }^{5}$.

Analysis of macular changes showed the study groups to differ statistically significantly according

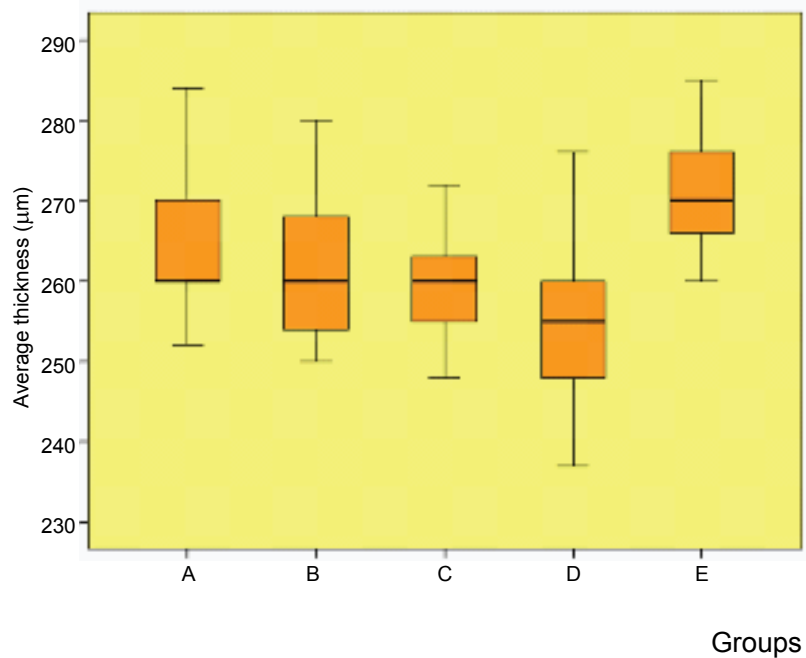

$\mathrm{A}=$ unilateral exfoliation syndrome (XFS) (fellow eye); $\mathrm{B}=$ unilateral XFS; C = bilateral XFS; D = bilateral exfoliative glaucoma;

$\mathrm{E}=$ control; ${ }^{*}$ reference values: 257.1-295 $\mu \mathrm{m}$

Fig. 2. Mean macular thickness according to study groups.

to the measured values of macular volume and mean macular thickness. The groups with unilateral and bilateral XFS, as well as control group had a statistically significantly higher macular volume than the group of XFG patients. The results of this study showed the mean macular thickness to be highest in control group, followed by the bilateral XFG, unilateral XFS and bilateral XFS groups, which was only partially consistent with literature data. Still, the hypothesis that structural changes had existed prior to functional ones, thus representing an early sign of glaucoma damage in the groups of patients at risk, i.e. those 
with unilateral or bilateral XFS, was confirmed. If the glaucoma had already manifested (XFG in this study) with changes in optic disc and visual field, structural changes confirmed the clinical findings and warned of the disease severity.

Studies have shown that macular thickness in glaucomatous eyes is significantly lower than that in healthy eyes ${ }^{6,10}$. Furthermore, significant correlation has been reported between the measured macular thickness on OCT and the mean visual field defect in glaucoma patients ${ }^{6}$. In their study, Medeiros et al. ${ }^{10}$ compared diagnostic precision of measuring macular thickness, RNFL measurements and optic disc with Stratus OCT. Comparison of macular thickness between glaucomatous and healthy eyes showed high overlapping of measured values in both groups of subjects ${ }^{10}$. That is why the newer software, which can isolate ganglion cell complex, can analyze specific indicators of macula and provide early detection of retinal ganglion cell loss.

In conclusion, our study showed that macular volume and macular thickness could be valuable indicators of glaucoma status. It is also important to emphasize that loss of macular volume, as well as a decrease in the mean macular thickness in the eyes with exfoliation, have an important role in early detection of glaucoma before changes in visual field have set in, and XFS (bilateral or unilateral) was identified as a risk factor for development of glaucomatous defects.

\section{References}

1. Ritch R. Exfoliation syndrome. The most common identifiable cause of open-angle glaucoma. J Glaucoma. 1994;3:3176-8.

2. Barišić F, Jurin Sičaja A, Malenica Ravlić M, Novak Lauš K, Iveković R, Mandić Z. Macular thickness and volume parameters measured using optical coherence tomography (OCT) for evaluation of glaucoma patients. Coll Antropol. 2012;36:441-5.

3. Pagliara MM, Lepore D, Balestrazzi E. The role of OCT in glaucoma management. Prog Brain Res. 2008;173:139-48. doi: 10.1016/S0079-6123(08)01110-2.

4. Stefan C, Dumitrica DM, Tebeanu E, Cristea I, Sapundgieva A, Dragomir I, et al. Macular involvement in glaucoma. Ophthalmologia. 2008;52:98-100.

5. Manasia D, Voinea L, Vasinca ID, Alexandrescu C. Correlation between macular changes and the peripapillary nerve fiber layer in primary open angle glaucoma. J Med Life. 2014;7:55-9.

6. Greenfield DS, Bagga H, Knighton RW. Macular thickness changes in glaucomatous optic neuropathy detected using optical coherence tomography. Arch Ophthalmol. 2003;121(1):41-6.

7. Schmidt U. Macular thickness for glaucoma diagnosis. Klin Monatbl Augenheilkd. 2010;227(12):981-6. doi: 10.1055/s0028-1110003. Epub 2010 Mar 24. German.

8. Giovannini A, Amato G, Mariotti C. The macular thickness and volume in glaucoma: an analysis in normal and glaucomatous eyes using OCT. Acta Ophthalmol Scand. 2002;236:34-6.

9. Lederer DE, Schuman JS, Hertzmark E, Heltzer J, Valazquez LJ, Fujimoto JG, et al. ub medAnalysis of macular volume in normal and glaucomatous eyes using optical coherence tomography. Am J Ophthalmol 2003;135(6):838-43.

10. Medeiros FA, Zingwill LM, Bowd C, Vessani RM, Susanna R Jr, Weinreb RN. Evaluation of retinal nerve fiber layer, optic nerve head, and macular thickness measurements for glaucoma detection using optical coherence tomography. Am J Ophthalmol. 2005;139:44-5. 
Sažetak

\section{KORELACIJA IZMEĐU PROMJENA MAKULE U EKSFOLIJACIJSKOM SINDROMU I EKSFOLIJATIVNOG GLAUKOMA}

\section{M. Šimić Prskalo, Ž. Tomić, K. Novak-Lauši Z. Prskalo}

Cilj studije bio je procijeniti prosječnu debljinu žute pjege i njen volumen kod jednostranog i obostranog eksfolijacijskog sindroma te ih usporediti s eksfolijacijskim glaukomom i kontrolnom skupinom. U tu svrhu koristila se optička koherentna tomografija. Ovo prospektivno ispitivanje uključilo je 114 ispitanika (228 očiju) koji su podijeljeni u 4 skupine s obzirom na prisutnost eksfolijacije: 30 ispitanika s unilateralnim sindromom, 24 ispitanika s bilateralnim sindromom, 28 ispitanika s obostranim glaukomom i kontrolna skupina koju su činila 32 ispitanika bez eksfolijacijskog sindroma ili glaukoma. Svi su ispitanici bili stariji od 50 godina. Ispitanici koji su imali vidnu oštrinu manju od 0,6 po Snellenu kao i oni s refrakcijskom greškom, tj. hipermetropijom većom od +3 sferne dioptrije, miopijom većom od -5 sferne dioptrije i astigmatizmom većim od 2 cilindrične dioptrije isključeni su iz studije, kao i ispitanici s dijabetičnom retinopatijom, makularnom degeneracijom ili edemom, epiretinom membranom, vaskularnom bolesti mrežnice, neuropatijom te ispitanici koji su prethodno imali operacijski zahvat na oku, osim pseudofaknih bolesnika s vidnom oštrinom unutar zadanih vrijednosti. U radu je potvrđena hipoteza o postojanju strukturnih promjena žute pjege prije funkcionalnih, što predstavlja rani znak glaukomskog oštećenja u rizičnim skupinama ispitanika kao što su oni s jednostranim ili obostranim eksfolijacijskim sindromom. Ako se već radilo o manifestnom glaukomu (u ovom radu eksfolijacijskom) s postojećim promjenama na glavi vidnoga živca i vidnom polju, strukturne su promjene upotpunile kliničku sliku i upozorile na težinu bolesti.

Ključne riječi: Žuta pjega; Glaukom; Eksfolijacijski sindrom 